\title{
The Sound of the Sundial (Zvuk slunečních hodin)
}

\author{
Author: Hana Andronikova
}

First Published: 2001

Translations: Belarusian (Guk sonečnaga gadzinnika, 2005); Hungarian (A napóra hangja, 2005); Bulgarian (Zvucite na slănčevija časovnik, 2006); English (The Sound of the Sundial, 2015).

About the Author: Hana Andronikova (1967-2011) was a Czech author and playwright. She was born in Zlin in Moravia, studied Czech and English at the Faculty of Arts, Charles University in Prague, graduating in 1992. She worked as a personal manager, in 1999, she started devoting most of her time to writing, travelling and life coaching. She came down with cancer and unsuccessfully underwent natural treatment in the jungle in the Amazon Rainforest (see autobiographical motifs in the novel Heaven Has No Bounds). Her characters are usually depicted in exceptional situations withstanding the pressures of difficult life circumstances.

Further Important Publications: Srdce na udici (2002, A Man's Heart Is in His Fishing Tackle; short stories); Nebe nemá dno (2010, Heaven Has No Bounds; autobiographical novel); Vzpomínky, co neuletí (2014, Memories That Will Not Fly Away; collection of short stories).

\section{Content and Interpretation}

The author remarks in the introduction: "This novel is fiction. It deals with historical documents (records from archives, old newspapers and reports, testimonies of witnesses) as well as with real characters which are modified and fade into fictional characters" (Andronikova, 2008, p. 4). At the end of the book, the literature concerning the Holocaust, World War II and mythology is listed (p. 301).

The novel is divided into 18 chapters. It begins with the background story in December of 1989 located in Breckenridge (Colorado in the U. S.). The main narrator of the story is Daniel Keppler, a Czech who has lived four decades in America. Now 68 years old, he is spending his winter holiday here with his family. By chance, the older owner of the small hotel, Anne Vanier, is also a Czech. It turns out that Anne was the best friend of Daniel's mother, Rachel during World War II when they both were imprisoned in Theresienstadt, in Auschwitz and in the forced labour camp in Hamburg. Daniel and Anne tell each other about their past. Their stories blend together and the background story of 1989 returns from time to time.

Daniel is the son of a construction engineer Thomas (Tomáš) Keppler who came from a half Czech and half German family and his wife Rachel from a Czech-German Jewish family. Thomas is hired by Bata, a company, founded in the Moravian town of 
Zlin that has become the largest shoe producer in the world. At the beginning of the 1930s, Thomas is charged with the building of a new production complex for Bata near Calcutta, in India. After two years, Rachel and the little Daniel also move to India. They are shocked but also fascinated by the completely different climate, culture and mentality of Indian people. In February of 1939 Rachel receives a message that her parents in Prague are both seriously ill. Although Thomas doesn't want to visit the land threatened by the Nazis, Rachel insists on returning. Her parents die, the family moves back to Zlín. Thomas gets a new job in Argentina. Nevertheless, it is too late, the war breaks out and everyone must stay in the occupied Czech lands.

In January of 1944 Rachel, officially living in a "mixed marriage", is transported to the Theresienstadt Ghetto. Now in 1989 Daniel learns about her from Anne who had been Rachel's fellow prisoner and a younger friend. In Theresienstadt Rachel cares for old and sick people and gives lectures about history and mythology. Thomas intervenes with his German relatives and it is promised to him, his wife would not leave Theresienstadt. However, Rachel accompanies Anne to the transport to Auschwitz and so she is also incorporated into it. In Auschwitz, the living conditions of the prisoners are much worse. Anne has sex with a Polish prisoner-kapo to gain food and shoes. Later she is raped by an SS-guard. Both, Rachel and Anne, are able to leave Auschwitz for a labour camp in Hamburg. In April of 1945, they are transported to Bergen-Belsen that is soon liberated by the British army. Nevertheless, Rachel is too exhausted and weak, to make it home, so she dies on the way to Prague. Anne, like Rachel, is on the threshold of death but is saved by the American soldier Pete Vanier, her future husband. They move together to the U. S.

Also David as a mischling (half-breed) is threatened with deportation to Theresienstadt. His father fakes David's death from typhus, his old friend doctor Bartošík makes a death certificate out and David survives the rest of the war in hiding. After the war, Thomas Keppler, desperate about the death of his wife as well as the power of the communists, emigrates with his son David to Toronto, Canada. David studies law and marries a Canadian girl. Only after many years he learns about the last months of his mother's life.

The novel can be interpreted as a typical postmodern work. Various narratives, levels of time and genres are blended here: the exotic novel about India, the Holocaust novel and the stories of romance and tragic love (Thomas and Rachel, Anne and the musician Gideon Klein in Theresienstadt, the SS-man Pestek and the Jewess René in Auschwitz). The novel contains many documents about the war and the Shoah. Some of these are real actual documents, some are fictional creations of the author's imagination (for instance news from Czech newspapers proving the Nazi persecution of the Jews or the diary of Pete Vanier, the American soldier fighting in Europe).

\section{Main Topics and Problems}

Hana Andronikova wrote her novel from 1998 to 1999, shortly after the genocide in Srebrenica in Bosnia (July 1995) and during the war in Kosovo (1998-1999). So both 
main themes of the work, the clash of civilisations and cultures in India on the one hand and the Holocaust in Europe on the other hand, can be seen as a parallel to these contemporary events.

The sundial from the title of the book and the Sun appear several times in the text. Rachel who is interested in fairy tales and myths, tells her son the Aztec story about the origin of the Sun (pp. 51-52), about the tribe of Mixtecs in Mexico and the Sun (pp. 67-68) and the love of the Sun for a human girl, that she remembers later in Auschwitz (pp. 185-186). At the end, David similarly recalls the sundial in Jantar Mantar in India, the biggest sundial in the world. According to Olga Zitová, these images present a paradox of the period of time during the war. These and other tales intend to instill hope, that the story of Keppler family and the Holocaust in general will be not forgotten (Zitová, 2014, p. 310). While depicting Rachel's dying, the narrator (or the author) comments: "We are stories. We are myths and fairy tales. We are poetry. Our lives are books" (Andronikova, 2008, p. 281).

Many real characters, mainly in Theresienstadt and Auschwitz, appear in the novel, like the SS officers and guards Karl Rahm, Josef Mengele and Maria Mandl, the Jewish prisoners Egon Redlich, Rafael Schächter, Karel Švenk and Gideon Klein in Theresienstadt, René Neumann or Alma Rosé, niece of Gustav Mahler, in Auschwitz.

In The Sound of the Sundial some important topics and motifs of Holocaust literature can be found. For instance, it is naivety of Rachel who does not believe that the Nazi persecution of the Jews will be so brutal. It is in contrast with her pragmatic husband Thomas refusing to return to the Czech lands in 1939. Another motif is scepticism about God, his omnipotence and his existence at all. While her Orthodox Jewish parents prohibit Rachel her relationship to the "goy" Thomas, she is convinced God must be thickheaded and dogmatic. Later Anne, Pete and Rachel ask the question how it is possible that God allows the brutal killing and death of so many innocent victims. See Elie Wiesel's Night, Viktor Fischl's novel $\rightarrow$ Court Jesters, Otto Weiss' short story $\rightarrow$ And God Saw That It Was Bad, Emil Knieža's novel $\rightarrow$ The Sixth Battalion, On Guard! or Hana Bořkovcová's novel $\rightarrow$ A Private Conversation. Also the traumatic return of survivors and their feelings of guilt (Anne) is a common motif in Holocaust literature. Not so frequent are the characters of the "good Germans", who meet Rachel and Anne mainly in Hamburg (pp. 190 and 233) $\rightarrow$ Death Is Called Engelchen (Ladislav Mňačko).

\section{Cited Works}

Andronikova, H. (2008). Zvuk slunečních hodin, 2nd modified ed. Praha: Euromedia Group - Odeon. Zitová, O. (2014). Zu Hana Andronikova’s Roman „Zvuk slunečních hodin“. In: R. Ibler, ed., Der Holocaust in den mitteleuropäischen Literaturen und Kulturen seit 1989. The Holocaust in the Central European Literatures and Cultures since 1989. Stuttgart: ibidem, pp. 303-315. 


\section{Further References}

Bajaja, A. (2012). Hana Andronikova. Zvuk Zlínského kraje, 23(1), pp. 88-89. Available at: 00155d01270c\#periodical-periodicalvolume-periodicalitem-page_uuid:a87e2bb61ce8-11e6-879f-005056af3e2c [Accessed: 01.09.2019]. Jindra, M. (2001). Několik osobních dojmů místo doslovu. In: H. Andronikova, Zvuk slunečních hodin. Praha: Knižní klub, pp. 284-285. Jungmann, M. (2002). Objev roku. Mosty, 11(44), p. 13. Machala, L. (2015). Oceňovaná, ale nedoceněná. Nad tvorbou Hany Andronikové. Tvar, 26(15), p. 15. Novotný, V. (2008). Ta naše postmoderna česká. Kritické vizitky literární současnosti. Praha: Protis, pp. 9-12. Stehlíková, O. (2012). Zvuk poznání v prózách Hany Andronikovy. iLiteratura.cz, 19. 1. Available at: http://www.iliteratura.cz/Clanek/29419/ andronikova-hana [Accessed: 01.09.2019]. 